\title{
Die skepping binne die raamwerk van die natuurwette
}

Daar is dinamiek in die heelal. Sterre ontstaan en gaan dood. Sterrestelsels (o.a. galaksies) ontstaan en verouder tot amorfe strukture. Galaksies beweeg uitmekaar (rooiverskuiwing van spektraallyne). Het die heelal 'n begin gehad of was dit maar altyd daar? Daar was tot in die sestigerjare aanhangers van albei standpunte: die oerknalteorie, waarvolgens die heelal vanaf ' $n$ begintoestand met 'n hoë temperatuur en digtheid - so hoog dat slegs elementêre deeltjies en straling kon bestaan - uitgesit en ontwikkel het tot sterre en galaksies soos ons vandag nog waarneem. Daarteenoor was daar die stasionêre kosmologiese model waarvolgens die heelal 'n konstante materie/energiedigtheid gehandhaaf het deur 'n voortdurende skepping van materie vanweë die uitdying.

In 1964 - 65 het Arno A. Penzias en Robert W. Wilson van die Bell Laboratories warmtestrale (kosmiese mikrogolfstrale) wat uit alle rigtings uit die heelal na ons kom, gemeet. Waar die stasionêre kosmologiese model die bestaan van hierdie strale nie kan verklaar nie, het die oerknalmodel die algemeen aanvaarde kosmologiese model geword. Volgens laasgenoemde model is die warmtestrale in die mikrogolfgebied die afgekoelde nagloed van die oerknal. Die spektrum van hierdie strale volg noukeurig 'n swartstraalspektrum met ' $n$ temperatuur van 2,73 kelvin. Dit is dan ook die temperatuur wat verwag word nadat die heelal vanaf die hoë temperatuur en hoë digtheid in 'n baie klein ruimte tydens die oerknal tot sy huidige grootte uitgesit en afgekoel het. Hierdie warmtestrale was skynbaar buitengewoon glad (dieselfde spektraalintensiteit en temperatuur in alle rigtings en in tyd), met ander woorde struktuurloos.

Volgens die teoretici het elementêre deeltjies tydens die oerknal ontstaan, waaruit waterst of en helium gevorm is, wat weer saamgeklont het om sterre te vorm. Straling en materie was steeds in temperatuurewewig met mekaar sodat die spektrum van die straling dié van 'n swart liggaam was. Die straling moes ook geringe variasies in temperatuur, dit is in digtheid, gehad het om as saad vir die saamklonting van materie deur swaartekrag tot die vorming van sterre te dien, en daarna weer vir die saambondeling van sterre tot galaksies, van galaksies tot trosse en tot supertiosse. Die vorming van hierdie strukture moet dan ook in die reste van die swartstraalspektrum van die oerknal afgedruk wees.

In April 1992 het George P. Smoot en kollegas van die Universiteit van Kalifornië en van die Lawrence Berkeley Laboratorium gegewens vrygestel wat hierdie gaping in die oerknalteorie gevul het. Ontleding van data ingesamel deur apparaat op die satelliet COBE (Cosmic Background Explorer) het geringe variasies in temperatuur van die mikrogolfstraling getoon, volgens die verwagting van die oerknalteoretici.

Kosmologie het deur hierdie en ander waarnemings en teoretiese berekeninge die oerknalteorie as ' $n$ wetenskap gevestig. Einstein se algemene relativiteitsteorie en kwantumfisika (waaronder kernfisika) vorm die grondslag van hierdie wetenskap. Volgens kwantumfisika het die heelal deur 'n kwantumfluktuasie in ruimte en tyd op 'n gegewe oomblik in 'n leë ruimte ontstaan. Die sogenaamde inflasionistiese teorie sorg dat die totale energie van die heelal nul is sodat daar geen verbreking van die wet van behoud van massa en energie plaasgevind het nie. Met die oerknal het ruimte en tyd deur die kwantumfluktuasie ontstaan en ontwikkel tot die ruimte wat tans die heelal omvat.

Daar bly nog enkele fundamentele vrae oor, eerstens, waarom bestaan die heelal uit die deeltjies (elektrone en protone o.a.) waaruit dit bestaan en nie uit ander soorte deeltjies nie? Die verwagting is dat hierdie antwoord uit die teorie van supergravitasie, 'n wiskundige teorie wat die hele fisika in een superwet wil omvat, sal kom. Die tweede fundamentele vraag is: waar kom die natuurwette (of dan die moontlike enkele superwet), waarvolgens die heelal, soos ons hom vandag ken, ontwikkel het, vandaan? Tyd en ruimte het met die oerknal ontstaan, en die natuurwette moes ook toe ontstaan het, maar hoe het hulle ontstaan? Hierdie vrae lei tot die vraag of 'n Skepper, 'n God buite die ruimte en tyd van die heelal, dit is, ' $n$ bonatuurlike God bestaan wat alles aan die gang gesit het en volgens sy wette laat verloop het, en of daar superkragte ('n natuurlike God) binne die heelal is, wat die evolusie van fisiese strukture en biologiese organismes rig en wat 'n beskrywing deur wiskundig gefundeerde natuurwette moontlik maak. Daar is (nog?) nie 'n natuurwetenskaplike antwoord op bogenoemde fundamentele vrae nie, trouens, 'n meganistiese heelal wat volgens natuurwette soos 'n klok werk, word vandag deur baie deskundiges nie aanvaar nie. Volgens die jongste natuurbeskouings (wêreldbeelde), wat uit onder andere die antropiese beginsel en die chaosteorie volg, kan 'n meganisties deterministiese heelal nie werk nie en daarom is so 'n heelal ook nie moontlik nie. Die alternatief is om te glo in 'n God (bonatuurlik of natuurlik) wat die skepping rig en lei binne die raamwerk van natuurwette. 


\section{Die Suid-Afrikaanse Akademie vir Wetenskap en Kuns in die Suid-Afrika van môre : anachronisme of aktualiteit*}

In 'n tyd van afwagting en onsekerheid is dit onvermydelik dat talle vrae gevra sal word. Dit is redelik om te verwag dat ook die bestaansreg van die Suid-Afrikaanse Akademie vir Wetenskap en Kuns krities onder die loep geneem sal word. Sal die Akademie in die sg. "nuwe Suid-A frika" dalk 'n ding wees wat chronologies uit sy plek sal wees? Sal die Akademie nog 'n funksie hê in hierdie nuwe bestel'? Sal die Akademie nie hopeloos uit pas en uit plek wees nie'? Sal dit nie 'n stuk anachronisme wees waarvoor'n museum as skuilplek gebou moet word nie? Die vraag is ook of die Akademie nog aktueel sal wees. Sal dit nog van belang wees vir die sake van die dag en vir die mense van môre? Sal dit nog 'n betekenisvolle geluid kan maak wat 'n bydrae tot 'n beter samelewing sal lewer?

Die Akademieraad het reeds 'n paar jaar gelede oor hierdie en ander vrae besin. Dit het uitgeloop op die wysigingswet op die Suid-Afrikaanse Akademie vir Wetenskap en Kuns wat in 1991 deur die parlement goedgekeur is. In hierdie wet word die oogmerke van die Akademie soos volg geformuleer: "Die oogmerke van die Suid-Afrikaanse Akademie vir Wetenskap en Kuns as interdissiplinêre organisasie is die bevordering van die wetenskap, die tegniek en die kunste en die bevordering van die gebruik en gehalte van die Afrikaanse taal."

Ten einde hierdie oogmerke te verwesenlik, beywer die Akademie hom daarvoor om:

- probleme van openbare belang te ondersoek en op grond van die bevindinge meningvormend en adviserend op te tree;

- gesaghebbend en normerend op te tree ten bate van die gebruik en ontwikkeling van Afrikaans in al sy funksies;

- deur wetenskaplike tydskrifte, handboeke. vakwoordeboeke, ander publikasies en aksies die wetenskap, die tegniek en die kunste en die gebruik en ontwikkeling van Afrikaans te bevorder;

- hoogstaande prestasies op die verskillende terreine van die kultuurlewe te bevorder en uitnemendheid met pryse en toekennings te bekroon;

- enige regte en voorregte te verkry en alles te doen wat hy vir die bereiking van sy oogmerke nodig of nuttig ag;

- gereeld oor sy struktuur, organisasie en programme te besin.

Die Akademie beskik oor 'n kolossale denkvermoë wat moontlik nog nooit ten volle benut is nie. Dit kan as spreekbuis en meningvormer van feitlik alle dissiplines optree. Hierdie invloed van die Akademie is dan ook meermale in die verlede gebruik om akademiese denke in praktiese skeppinge om te skakel. Die Akademie se aandeel in die ontstaan van die RGN, die Afrika-instituut, die Vakterminologiediens, die Stigting Simon van der Stel, die Fakulteit Geneeskunde aan die Universiteit van Pretoria (die eerste mediese fakulteit met Afrikaans as voertaal), die Buro vir Heraldiek, die FAK, die Stigting vir Afrikaans, ens.. is voorbeelde hiervan.

Die Nasionale Vakterminologiediens, vroeër die Vaktaalburo. lewer saam met die Akademie 'n belangrike bydrae tot die bevordering en uithouing van die Afrikaanse vaktaal en wel by wyse van vakwoordeboeke. Die volgende woordeboeke wat sedert 195() gepubliseer is, kan genoem word: Bouwoordeboek, Sterrekundewoordeboek, Ekonomiewoordeboek, Musiekwoordeboek, Teaterwoordeboek, Fisikawoordeboek, Plantkundewoordeboek, Chemiewoordeboek, Plastiekwoordeboek, Biblioteekwoordeboek, Filateliewoordeboek, Ingenieursterme en andere.

Daar bestaan kommer oor die feit dat die Vakterminologiediens as gevolg van 'n tekort aan geld nie vinnig genoeg vorder met sy werk nie. Dit is veral dringend noodsaaklik dat daar dinamiese vordering sal wees in die nuwe tydvak wat ons gaan betree. Ons verwag ekonomiese opbloei en ook groot vordering op tegnologiese gebied. Die taal mag nie in hierdie wedloop agterbly nie.

Afgesien van sy publikasies, die werk van sy kommissies, ens., word daar verskeie lesings, referate, voordragte en so meer aan die bevordering en ontwikkeling van die Afrikaanse taal en kultuur gewy. Die Akademie bekroon ook jaarliks werk van buitengewoon uitnemende gehalte gelewer deur persone op hul onderskeie terreine. Met hierdie toekennings probeer die Akademie die Afrikianse letterkunde, kuns, wetenskap en geskiedenis bevorder.

In die Fakulteit Natuurwetenskap en Tegniek word die volgende pryse toegeken:

M.T. Steynmedalje vir buitengewome natuurwetenskaplike en tegniese prestasie; die Havengaprys in die vakgebiede Wiskunde, Fisika, Geneeskunde, Chemie, Biologie, Ingenieurswese, Geologie. Boukunde en Landbouwetenskappe; die Goue Akademiemedalje vir natuurwetenskaplike prestasie; die SA Vervoerdienstemedalje; die Erepenning vir wetenskaplike vakbevordering; die Junior en Senior Kaptein Scottmedaljes en die Albert Stratingprys vir Voorkomende Geneeskunde.

Die maatstal van die Akademie in al sy bekronings is voortretlikheid en uitnemendheid. Dit is van die allergrootste belang dat standaarde in enige nuwe bedeling hoog gehou moet word. Die Akademie moet daarin steeds leiding gee.

Die SA Akademie verleen hoë prioriteit aan onderwyssake en die Onderwyskommissic adviseer die Akademieraad oor alle sake rakende die onderwys. 'n Baie belangrike onderwysprojek van die Akademie is die Wiskunde-olimpiade waaraan sowat 20000 leerlinge vanoor die hele Republiek en Namibië jaarliks deelneem. Die doel van die olimpiade is om Wiskunde op sekondêre skoolvlak te stimuleer en te ontwikkel en om leerlinge vir deelname alan internasionale olimpiades voor te berei. Die Akademie doen ook belangrike werk in verband met die skryf van Afrikaanse handboeke vir studente aan Afrikalanse universiteite, o.a. handbocke in Wiskunde, Fisika en Chemie. Meer as 70000 Afrikaanse handboeke is al in die hande van studente geplaas.

'n Wye reeks wetenskaplike tydskrifte en ander publikasies word deur die Akademie gepubliseer, nl. die Tydskrif vir Geesteswetenskappe, die SA Tydskrif vir Natuurwetenskap en 'Tegnologie, die Nuusbrief, die Jaarbock, die

*Uittreksel uit die Eugène Marais-gedenklesing wal op 3 Junie 1992 in Pretoria gelewer is. 
Christiaan de Wetannale, die Hertzoggedenklesing, die Jaarverslae, Afrikaanse Teksuitgawes, Afrikaanse Voorname, Akademiepryse en Afrikaanse Etimologieë.

Een argument wat dikwels gehoor word, is dat Afrikaans as publikasietaal besig is om te verdwyn. Daar word dan gewys op die feit dat natuurwetenskaplikes hoofsaaklik in Engels publiseer. Op grond hiervan word Afrikaans dan afgeskryf as minderwaardig en oor sy toekoms word groot vraagtekens geplaas. So 'n houding is nie alleen onbillik nie, maar getuig ook van 'n verbasende onkunde. Toe die eerste blankes in Tafelbaai voet aan wal gesit het, het hulle Hollands gepraat. Afrikaans sou eers eeue daarna as taal erken word. Maar toe reeds was Engels, Frans en Spaans eeue-oue wêreldtale met 'n ou gevestigde wetenskaplike vaktaal en wetenskaplike tradisie. Moes Afrikaans in sy kort bestaan nog hierdie agterstand ook ingehaal het? Die feit dat wetenskaplikes wat internasionaal gelees wil word van 'n internasionale taal gebruik maak om hulleself verstaanbaar te maak, is geen verraad teenoor Afrikaans nie. Dit is ook geen rede om Afrikaans te wil afskryf nie. Afrikaanse vaktydskrifte, Afrikaanse handboeke, Afrikaanse woordelyste en tydskrifte bewys immers dat Afrikaans as publikasietaal wel hier tot sy reg kom.

In hierdie verband sal die Akademie in die toekoms ' $n$ al hoe groter rol moet speel om te verseker dat Afrikaans as wetenskapstaal sal bly voortbestaan.

\section{Het die Akademie en Afrikaans 'n toekoms?}

Die voortbestaan van die Akademie is onlosmaaklik verbind aan die voortbestaan van Afrikaans. Die antwoord op die vraag lê verder êrens in geloofsvertroue, liefde vir die eie, onvoorwaardelike toewyding en onbaatsugtige diens. As hierdie elemente deel is van ons toekomsfilosofie, sal Afrikaans en daarmee saam die Akademie steeds aktueel bly voortbestaan.

D.J.C. GELDENHUYS 